\title{
ANNUAL VARIATION IN SERUM LIPID PROFILE OF THE INDIAN MALE \\ FLYING FOX Rousettus leschenaulti (DESMEREST)
}

\section{Archana Masram}

LAD \& Smt. R. P. College for Women, Nagpur, Maharashtra, India

Corresponding author Email : amg123321@gmail.com

\begin{abstract}
:
Although bats of the genus Rousettus are important ecologically as pollinators and natural hosts for zoonotic pathogens, little is known about their basic physiology. Therefore lipid profile which includes cholesterol and triglyceride have been analyzed. Cholesterol is a waxy fat used for cellular function and production of hormone and triglyceride, which is the main storage form of fat in the body, serves as building blocks for cells and are used to create energy, is synthesized in the liver from proteins and carbohydrates, and also come from the fats in food. For the present study the blood serum of 36 male Indian fruit bats, Rousettus leschenaulti (Desmerest) was analyzed in a complete calendar year from their natural roost, Mansar /

Kandri mines, Nagpur, Maharashtra $\left(20^{\circ} 2^{\prime \prime N}, 78^{\circ} 95 \mathrm{E}\right)$. The highest values were recorded during May- September and December, depicting less exposure to stress, less utilization of required energy resulting into less dehydration of body fluids. In March the significant decline was recorded in serum triglyceride level and relatively (intermediate) constant-values were recorded during rest of the months January, February, April, May, October and November. A significant decline in the March might be due to breeding stress, and probably enhancement in the sexual behavior, aggressive approach towards female, competition among males and onset of summer. Such studies provide basic physiologic information that can be used in future for health and disease studies of Indian flying fox.
\end{abstract}

Keywords:

Cholesterol, Triglyceride, flying fox

\section{Introduction:}

The blood composition be used as an indicator for evaluating the health and well-being of mammals, similarly concerning their role in the pathogenesis of rabies more information is needed regarding their ecology and physiology (Halloran and Pearson, 1972; Koopman et al., 1995)Blood parameters are dynamic values that can vary in complex ways with a variety of factors, including season, sex, age, nutritional state, stress, capture method, 
anesthesia and extrinsic factor (e.g. month, method) (Seal et al., 1972 a,b; Wesson et al., 1979). Blood analysis is an important tool in searching for corrections of blood elements and mutational condition of disease. The greatest biological diversification is observed among the bats of the tropics and subtropics due to varied behavioral, morphological and physiological specializations and adaptations (Krutzsch and Wimsatt, 1963). Analysis of lipid profile is useful as an index of health to nutrition and season, physical and exertion stress in humans and animals (Powell and DelGiudice, 2005).

\section{Material and Method:}

The specimens of Rousettus leschenaulti were collected with the help of mist net placed in the underground mines of Mansar / Kandri Near Nagpur, Maharashtra $\left(20^{\circ} 92^{\prime \prime} \mathrm{N} 78^{\circ} 95^{\prime \prime E}\right)$. Time of collection, body mass, wing span, length of forearm and other salient features of each specimen were maintained in the field diary and then each male was transferred to an individual comfortable cage. These traps were transported to the RTM Nagpur University Laboratory. Minimum noise, human exposure and handling were employed to minimize capture stress and excitement. For each sampling, three bats were used. For blood sampling the bats were held in hands and no anesthesia was used at the time of sample collection $2 \mathrm{ml}$ of blood was collected into sterile tube with no anticoagulants (neither EDTA nor heparin). The Serum cholesterol (CHOD_PAP method,Tietz,1999) and serum triglyceride (GPO-PAP, end point assay (Nader et al, 1994) estimation was performed using a technicom semiauto analyser (RA-50 Technocom, Germany) with The data was analysed statistically; standard errors were calculated on the basis of which graphs were plotted to compare the seasonal variations.

\section{Result and Discussion:}

The mean range during the annual cycle of $R$. leschenaulti was noted to be 10.27 to $23.90 \mathrm{mg} / \mathrm{dl}$, highest values being in the month of May, June, July 
which happens to be the reproductively quiescent period, the utilization of cholesterol might have been less since they are the precursors of testosterone whose value being at decline. On the contrary the serum cholesterol level declined in November and March, which is the breeding period of the Rousettus and the testosterone values were at the peak, emphasizing the utilization in the synthesis of testosterone (Table-1, fig. 1) and the approximate range of mean values of triglyceride were recorded to be $9.93 \mathrm{mg} / \mathrm{dl}$. to $22.30 \mathrm{mg} / \mathrm{dl}$. The highest values were recorded during June-September $(20.07$ to $21.33 \mathrm{mg} / \mathrm{dl})$ and December $(21.40 \mathrm{mg} / \mathrm{dl})$ depicting less exposure to stress, less utilization of required energy and the pleasant rainy season, not resulting into dehydration of body fluids. In March the significant decline was recorded in serum triglyceride level $(9.93 \mathrm{mg} / \mathrm{dl})$ and relatively (intermediate) constantvalues were recorded during rest of the months January, February, April, May, October and November. A significant decline in the March might be due to breeding stress, and probably enhancement in the sexual behavior, aggressive approach towards female, competition among males and onset of summer (Table-1, fig. 2). The annual variations in the cholesterol values for Rousettus appears to be in consonance with various factors described for mammals including a few notes on other Chiropteran species. Thus our results on cholesterol and testosterone are in agreement with the statement of Duell and Bierman (1990) that there is significant corelation between the endogeneous sex hormones and high-density lipoprotein (HDL) cholesterol levels in healthy men. All classes of plasma lipids (cholesterol, total glycerol and phospholipids) during late fall-early winter, that is during the period of the year when plasma levels of both thyroxine and testosterone were minimal, plasma lipids subsequently decreases to minimal levels either in early summer and become detectable as trace components during cold months (Laplaud et al., 1989). At the same time assessment of environmental stresses, rapid food-passage time, and oxygen-consumption data support the hypothesis that there must be a great capacity for change in blood morphology and blood chemistry of bats. 
Multiple linear regression analysis identified several factors are correlated highly significnalty with cholesterol levels, including alcohol intake, frequency of strenuous exercise, age, levels of cholesterol, triglycerides etc. (Duell and Bierman, 1990). The base line data on cholesterol values are essential tools for assessing health in humans and animals (Peinado et al., 1996; Smucney et al., 2001) or these data can serve as a useful baseline for both captive and animals (Bush, 1991; Broughton 2nd, 1992) or important in the studies of small population size, those are vulnerable to local extinction, restricted distribution and relatively specialized resources use-such as spotted skunk (Crooks et al., 2003). Cholesterol exhibited higher ranges since they are more sensitive to recent diet or alternating bouts of nursing and nutritional deprivation (Powell and DelGiudice, 1995; Sam et al.,1995). Card et al., 1985 also noticed that these changes are associated thyroid activity. According to these authors serum cholesterol is relative low but in keeping with the trend among herbivores but rarely in carnivores and hence dietary habit is of great importance in determining serum cholesterol levels. Lower cholesterol values indicates moderately reduced fat intake (Seal et al., 1975). Cholesterol levels in blood is of great biological significance, this difference probably is due to the diet and the sedimentary life of the captivity (Currier and Russel, 1982; Keiver et al., 1987). An additional difference might be the amount of frequency of meals. Similarly the values are lower in new born fawns from captive does fed a low protein level (Sam et al., 1995). Similarly a relationship exist between seasonal variation in blood biochemistry, shifts in diet and body condition in a single population of white tailed deer (Moen, 1978; Hawley, 1987). Since triglycerides are the storage form of fat in the body, serving as building blocks for cells and utilized to create energy they are to be broken down to fatty acids and glycerol by lipase as the first step in the use of fat for muscular energy (George and Talesara, 1962; George, 1964). As described previously the increase or decrease in the values are subjected to intrinsic and extrinsic factors, thus the increases in plasma-free fatty acids as coupled with the 
decrease in liver triglycerides and free fatty acids is reported by Esher et al. (1973); Heard and Whittier (1997). The stressful effect of restraint and handling must be considered when measuring blood parameters and interpreting the results (Chapple et al., 1991; Lander et al., 2003). Stress resulting from fear, excitement, apprehension or handling can cause the levels of triglyceride increases when rats are exposed to cold and to low quality food (Alfaro et al., 1994; DelGiudice et al., 1994). Similarly a study on Rousettus aegyptiacus in captivity showed that triglyceride levels undergo daily changes, high levels being in evening and low in the morning (Westhuyzen, 1978), similarly an increase in serum triglycerides during hibernation in captive black bears (Nelson et al., 1973). In consonance the levels of triglyceride of bats, Rousettus aegyptiacus captured near lilia trees were significantly higher than that of bats caught near of carob and loquat trees whereas the triglycerides level of bats caught near mulberry trees were intermediate (Korine et al., 1999). The baseline data on triglycerides values are essential tools for assessing health in humans and animals (Heidt and Hargraves, 1974). From the foregoing it is concluded that in male R.leschenaulti the approximate range of mean values of lipid profile which were recorded are comparable to other mammals including bats throughout the annual cycle subjective to all the factors aforementioned.

\section{Conclusion:}

In conclusion moreover, our studies were comparable to the previous studies on non hibernating bats and other mammals. At the same time this baseline data on physiological characteristics of blood lipid profile is essential in the management of wild animals and hence conservation of species.

\section{Acknowledgement:}

Head, PGTD, Zoology, RTM Nagpur university, Nagpur 


\section{Reference:}

Alfaro V, Peinado VI, Palacios L (1994) Changes in plasma, glucose, lactate, triglycerides and some non-protein nitrogen components induced by short-term hypothermia in the conscious rat. Comp. Biochem. Physiol. (A) 107: 149-155.

Broughton G 2nd (1992) Hematologic and blood chemistry data for the prairie dog (Cynomys ludovicianus) Comp. Biochem. Physiol. Comp. Physiol. $101(4): 807-812$.

Bush BM (1991) interpretation of laboratory results for small animal Clinicians. Blackwell Scientific Publications, Oxford, UK. Card WC, Kirkpatrick RL, Webb KE, Scanlon PF (1985) Nutritional influences of nefa cholesterol and ketones in white- tailed deer. J. Wildl. Mang. 49 : 380-385.

Chapple RS, English AW, Mulley RC, Lepherd EE (1991) Hematology and serum biochemistry of captive unsedated chital deer (Axis axis) in Australia. J. Wildl. Dis. 27(3) : 396 - 406.

Crooks KR, Garcelon DK, Scott CA, Wilcoxe JT, Timm SF, Van vuren DH (2003) Hematology and serum chemistry of the island spotted skunk on Santa Cruz. J. Wildl. Dis. 39(2) : 460 - 466.

Currier MJ, Russel KR (1982) Hematology and blood chemistry of the mountain lion (Felis concolour). J. Wild1. Dis. 18(1) : 99-104.

DelGiudice GD, Mech LD, Seal US (1994) Undernutrition and serum urinary urea nitrogen of white tailed deer during winter. J. Wildl. Manag. 58 : 430-436.

Duell PB, Bierman EL (1990) The relationship between sex hormones and high density lipoprotein cholesterol levels in healthy adult men. Arch. Intern. Med. 150(11) : 2317-2320. 
Esher RJ, Fleischman AI, Lenz PH (1973) Blood and liver lipids in torpid and aroused little brown bats, Myotis lucifugus. Comp. Biochem. Physiol. 45: 933-938.

George JC (1964) Muscle lipase. J. Anim. Morphol. Physiol. 11: 233-243.

George JC, Talesara CL (1962) Lipase activity of the particulate fractions of the pigeon breast muscle and its significance in the metabolism of the muscle. J. Cell. Comp. Physiol. 60 : 33-40.

Halloran DW, Pearson AM (1972) Blood chemistry of brown bear (Ursus arctos) from south western Yukon territory, Canada. Can. J. Zool. 50 : 827-833

Hawley AWL (1987) Identifying bison ratio groups by multivariate analysis of blood composition. J. Wild1. Manage. $51: 893-900$.

Heard DJ, Whittier DA (1997) Haematology and plasma biochemical reference values for three flying fox species (Pteropus sp.) J. Zoo. Wildl. Med. 28 : $464-470$.

Heidt GA, Hargraves J (1974) Blood chemistry and hematology of the spotted skunk, Spilogale putorius. J. Mamm. 55(1) : 206 - 208.

Keiver KM, Chandler M, Frank RJ, Ronald K (1987) Plasma and blood volumes of hoded seal (Cystophora cristata). Can. J. Zool. 65 : 1866-1867.

Koopman HN, Westgate AJ, Read AJ, Gaskin DE (1995) Blood chemistry of wild harbor porpoises Phocoena phoceona (L) Mamm. Sci. 11 : 123-135.

Korine C, Zinder O, Arad Z (1999) Diurnal and seasonal changes in blood composition of the free living Egyptian fruit bat (Rousettus aegyptiacus). J. Comp. Physiol. 169 : 280-286.

Krutzsch PH, Wimsatt WA (1963) Some normal values of peripheral blood in the vampire bat. J. Mammal. 44(4) : 556-559. 
Lander ME, Harvey JT, Gulland FM (2003) Hematology and serum chemistry comparisons between free-ranging and rehabilitated harbor seal. (Phoca vitulina richardsi pups) J. Wildl. Dis. 39(3) : 600-609.

Laplaud MP, Sabourcall M, Beaubatie L, El-Omari B (1989) Seasonal variations of plasma lipids and lipoproteins in the hedgehog, an animal model for lipoproteins (a) metabolism : relation to plasma thyroxine and testosterone levels. Biochemica. et. Biophysica. Acta. (BBA) Lipids and Lipid metabolism. 1005(2) : 143-156.

Moen A N (1978) seasonal changes in heart rates, activity, metabolism, \& forage intake of white tailed deer. J. Wildl. Mang. $42: 715-73$.

Nader R, Paul B, John A, (1994) Lipids, Lipoproteins \& Apolipoproteins, In : Tietz Textbook of Clinical Chemistry, 3rd Ed. Burtis C.A. and Ashwood E.R., Eds. W.B. Saunders, Philadelphia, pp. 809-852.

Nelson RA, Wahner HW, Jones JD, Ellefson RD, Zollman PE (1973) Metabolism of bears before, during and after winter sleep. Am. J. Physiol. 224 : 491 496.

Peinado VI, Celdran JF, Viscor G, Palomeque J (1996) Hematology and serum chemistry in the white crowned mangabey (Cercocebus torquatus lunulatus) $\&$ in the mandrill (Mandrillus sphinx). J. Med. Primatol. 25(4): 282-286.

Powell MC, DelGiudice GD (2005) Birth, morphologic and blood characteristics of free ranging white-tailed deer neonates. J. Wildl. Dis. $41: 171-183$

Sam MG, Lochmiller RL, Hellgren EC, Payton ME, Varner LW (1995) Physiological responses of neonatal white-tailed deer reflective of maternal dietary protein intake. Can. J. Zool. 73: 1928-1936.

Seal US, Mech LD, Ballenberghe VV (1975) Blood analyses of wolf pups and their ecological and metabolic interpretation. J. Mammal. $56: 64-75$. 
Seal US, Ozoga JJ, Erickson AW, Verme LJ (1972a) Effects of immobilization on blood analysis of white-tailed deer. J. Wildl. Manag. 36 : 1034-1040.

Seal US, Verme LJ, Ozoga JJ, Erickson AW (1972b) Nutritional effects on thyroid activity and blood of white-tailed deer. J. Wildl. Mgmt. 36 : 10411052.

Smucny DA, Allison DB, Ingram DK, Roth GS, Kemnitz JW, Kohama SG, Lane MA, Black A (2001) Changes in blood chemistry and hematology variables during aging in captive rhesus macaques (Macaca mulatta). J. Med. Primatol. $30: 161-173$.

Tietz NW (1999) Textbook of clinical chemistry, 3rd Ed. Philadelphia : WB Saunders and Company, pp. 617-721.

Wesson JA, III. PF Scanion, Kirkpatrick RL Mosby HS (1979) Influence of chemical immobilization and physical restraint on packed cell volume, total protein, glucose, and blood urea nitrogen in blood of white - tailed deer. Can. J. Zool. $57: 756-767$.

Westhuyzen J van der (1978) The diurnal cycle of some energy substrates in the fruit bat (Rousettus aegyptiacus). S. Afr. J. Sci. 74 : $99-101$.

Table 1 - Pertinent data regarding collection of Rousettus lecshenaulti used for the present study. The number in parenthesis is for animals used. (Values are mean $\pm \mathrm{SE})$.

\begin{tabular}{|c|c|c|c|c|c|}
\hline $\begin{array}{c}\text { Specimen } \\
(\mathrm{n}=3)\end{array}$ & $\begin{array}{c}\text { Date of } \\
\text { collection }\end{array}$ & $\begin{array}{c}\text { Time of } \\
\text { collection }\end{array}$ & Body weight $(\mathrm{g})$ & $\begin{array}{c}\text { Total } \\
\text { Cholesterol(mg/dl) }\end{array}$ & Triglyceride(mg/dl) \\
\hline Male & $8 / 1 / 07$ & $10.10 \mathrm{am}$ & $111.33 \pm 1.86$ & $17.80 \pm 0.153$ & $15.20 \pm 0.173$ \\
\hline Male & $6 / 2 / 07$ & $10.45 \mathrm{am}$ & $113.33 \pm 1.67$ & $15.00 \pm 0.173$ & $12.17 \pm 0.203$ \\
\hline Male & $9 / 3 / 07$ & $10.10 \mathrm{am}$ & $128.00 \pm 1.53$ & $11.80 \pm 0.153$ & $9.93 \pm 0.120$ \\
\hline Male & $8 / 4 / 07$ & $10.45 \mathrm{am}$ & $100.00 \pm 2.89$ & $19.23 \pm 0.578$ & $17.20 \pm 0.173$ \\
\hline Male & $8 / 5 / 07$ & $11.00 \mathrm{am}$ & $98.00 \pm 0.58$ & $20.93 \pm 0.233$ & $18.33 \pm 0.088$ \\
\hline Male & $9 / 6 / 07$ & $10.10 \mathrm{am}$ & $95.00 \pm 2.65$ & $23.90 \pm 0.346$ & $20.07 \pm 0.233$ \\
\hline Male & $9 / 7 / 07$ & $10.45 \mathrm{am}$ & $93.00 \pm 2.52$ & $22.67 \pm 0.203$ & $22.30 \pm 0.208$ \\
\hline Male & $6 / 8 / 07$ & $10.35 \mathrm{am}$ & $70.67 \pm 0.67$ & $20.13 \pm 0.120$ & $20.03 \pm 0.291$ \\
\hline Male & $4 / 9 / 07$ & $11.30 \mathrm{am}$ & $71.00 \pm 1.0$ & $21.27 \pm 0.145$ & $21.33 \pm 0.088$ \\
\hline Male & $6 / 10 / 07$ & $12.00 \mathrm{noon}$ & $100.67 \pm 5.21$ & $17.13 \pm 0.186$ & $15.60 \pm 0.231$ \\
\hline Male & $9 / 11 / 07$ & 11.30 am & $121.67 \pm 1.67$ & $10.27 \pm 0.145$ & $18.03 \pm 0.145$ \\
\hline Male & $11 / 12 / 07$ & 11.30 am & $99.00 \pm 2.08$ & $23.10 \pm 0.208$ & $21.40 \pm 0.265$ \\
\hline
\end{tabular}



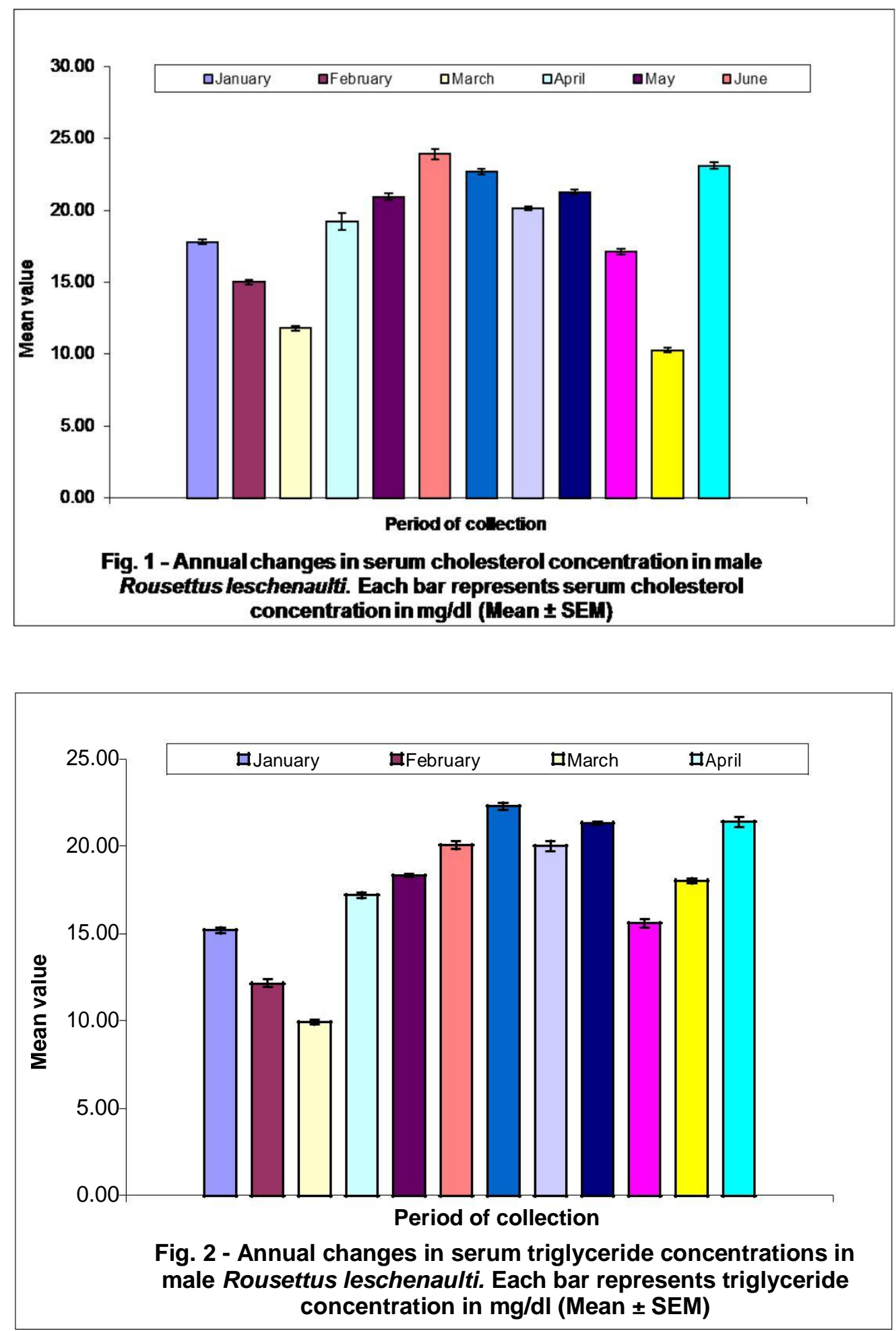

A Four Monthly Peer Reviewed Journal 